\title{
Rozwój technologii opartych na metodach biologii molekularnej do oznaczania grup krwi
}

\author{
Development of molecular biology methods for blood cell antigen \\ genotyping
}

\author{
Katarzyna Guz®, Agnieszka Orzińska®, Ewa Brojer@ \\ Zakład Immunologii Hematologicznej i Transfuzjologicznej Instytutu Hematologii i Transfuzjologii \\ w Warszawie
}

\begin{abstract}
Streszczenie
W ciagu ostatnich lat obserwuje sie gwattowny rozwój technologii badań molekularnych stosowanych $w$ immunohematologii. Na świecie sa one obecnie używane nie tylko przez laboratoria referencyjne $i$ wysokospecjalistyczne, lecz sa wdrazane do badan masowych $w$ centrach krwiodawstwa, gdzie stuża przede wszystkim do genotypowania klinicznie istotnych antygenów $w$ celu zwięsszenia dostępności dawców dla chorych z alloprzeciwciatami. W nieodlegtej przysztości będzie też możliwe dobieranie dla chorych zależnych od przetoczeń dawców zgodnych $w$ najbardziej immunogennych antygenach, tak by zapobiegać alloimmunizacji. Z myśla o tak ambitnych planach, sq opracowywane na świecie zaawansowane technologie, umożliwiajace masowe genotypowanie antygenów komórek krwi. W niniejszym artykule zostana omówione metody biologii molekularnej przydatne dla takich badań.
\end{abstract}

Słowa kluczowe: genotypowanie antygenów komórek krwi, nanofluidowa/cyfrowa reakcja łańcuchowa polimerazy, mikromacierze, spekrometria masowa MALDI-TOF, multipleksowa amplifikacja zależna od ligacji sond (MLPA), sekwencjonowanie następnej generacji (NGS)

J. Transf. Med. 2019; 12: 56-64

\begin{abstract}
Summary
In recent years, we have been observing the rapid development of molecular research technologies used in immunohematology. They are currently used not only by reference and highly specialized laboratories, but also for massive examinations in blood centers for genotyping clinically relevant antigens in order to increase the availability of donors for patients with allo-antibodies. In the near future, it will be possible to select donors compatible with patients in the most immunogenic antigens for preventing their alloimmunization. With such ambitious plans in mind, advanced technologies are developed around the world, to facilitate mass genotyping of blood cell antigens. The present study discusses molecular methods which may be used for this purpose.
\end{abstract}

Key words: blood cell antigens genotyping, nanofluidic/digital polymerase chain reaction, microarrays, mass spectrometry MALDI-TOF, multiplex ligation-dependent probe amplification (MLPA), next generation sequencing (NGS)

J. Transf. Med. 2019; 12: 56-64

Adres do korespondencji: prof. dr hab. n. med. Ewa Brojer, Zakład Immunologii Hematologicznej i Transfuzjologicznej IHiT, ul. Chocimska 5, 00-957 Warszawa, e-mail:ebrojer@ihit.waw.pl 


\section{Wstęp}

Postęp, który dokonal się w ciagu ostatnich lat w dziedzinie nowych technologii badań molekularnych, stosowanych $\mathrm{w}$ immunohematologii, jest omawiany szczegółowo w wielu publikacjach [1-3]. W niniejszym artykule omówiono wiodące metody i technologie, które są do tego wykorzystywane. Analogicznie, jak w ubiegłych latach, większość opracowywanych technologii opiera się na wykorzystaniu reakcji łańcuchowej polimerazy (PCR, polymerase chain reaction). Dla zapewnienia wysokiej sprawności badań dąży się do powielania wielu fragmentów genów w jednej reakcji PCR (tzw. multiplex PCR), a także unowocześniania techniki analizy produktów amplifikacji — na przykład poprzez zastosowanie elektroforezy kapilarnej. Ten rodzaj elektroforezy jest stosowany zarówno do rozdziału fragmentów DNA, różniących się wielkością (np. w technologii multipleksowej amplifikacji zależnej od ligacji sond — tzw. MLPA), jak i do rozdziału fragmentów DNA różniących się tylko pojedynczymi nukleotydami, co jest możliwe przy zastosowaniu barwienia odmiennymi fluorochromami (np. w technologi SNaPshot) $[4,5]$.

Wiele opracowanych testów jest opartych na hybrydyzacji DNA izolowanego $z$ badanych próbek do sond naniesionych na podłożach stałych (mikromacierze) lub na mikrokulkach zawieszonych $\mathrm{w}$ płynie (m.in. w technologii Luminex). Udoskonalane są także techniki badania produktu amplifikacji w czasie rzeczywistym (real-time PCR), poprzez miniaturyzację płytek reakcyjnych (tzw. nanopłytki) oraz konstruowanie wielu urządzeń do nich przystosowanych [6]. Istotną techniką wkraczającą do badań grup krwi jest spektrometria masowa $z$ wykorzystaniem źródła jonów MALDI $i$ analizatora TOF (technologia MALDI/TOF MS).

Analizuje się także przydatność technik opartych na cytometrii przepływowej, konstruując nanocząstki z przytwierdzonymi specyficznymi dla alleli sondami, by w prosty i szybki sposób identyfikować DNA bez konieczności jego amplifikacji [7].

Duże nadzieje wiąże się $z$ nowymi technologiami sekwencjonowania (NGS, next generation sequencing), pozwalającymi analizować wybrane regiony genomu, całe egzomy, a nawet całe genomy $\mathrm{w}$ jednym eksperymencie [8].

Wszystkie te metody wymagają odpowiedniego wyposażenia laboratorium, co w niektórych technologiach jest bardzo dużym wydatkiem inwestycyjnym. Ich zastosowanie do badań antygenów komórek krwi wymaga nie tylko wiedzy $z$ dziedziny biologii molekularnej, ale także immunohemato- logii, by rozwiązywać ewentualne rozbieżności wyników genotypowania i fenotypowania.

Ważnym elementem organizacji badań jest tworzenie cyfrowej bazy wyników, czyli profesjonalnego rejestru dawców $z$ oznaczonym genotypem antygenów komórek krwi, powiązanym $z$ systemem ewidencji donacji i badaniami serologicznymi.

W badaniach wykonanych za pomocą wymienionych wyżej technik, prowadzonych w różnych ośrodkach, wykazano wysoką zgodność wyników genotypowania i fenotypowania (tab. 1). Udowodniły to między innymi badania Watkins i wsp., w których 20266 oznaczeń alleli antygenów erytrocytów porównano $z$ archiwalnymi wynikami serologicznymi. Uzyskano 44 wyniki rozbieżne. Powtórzono badania serologiczne u 18/44 dostępnych dawców, przy czym dla ustalenia fenotypu konieczne było zastosowanie różnych metod serologicznych. We wszystkich 18 przypadkach pierwotne wyniki serologiczne były nieprawidłowe, a wyniki badań molekularnych prawidłowe - w tych przypadkach błędne okazały się wpisy wyników serologicznych w systemie komputerowym [9].

Błędy fenotypowania mogą wynikać $z$ niewykrywania antygenów o słabej ekspresji, a błędy po stronie metod genetycznych $z$ obecności mutacji w obrębie sekwencji, do której zaprojektowano startery/sondy. Przyczyną fałszywego wyniku genotypowania może także być mutacja w innym regionie genu, warunkująca brak ekspresji danego antygenu (allel wykryty genetycznie jest allelem „cichym”). Szczegółowe przykłady rozbieżności wyników fenotypowania i genotypowania antygenów komórek krwi zestawił Peyrard [15].

Przy odpowiednim opracowaniu warunków badania genetyczne są jednoetapowe i nie wymagają stosowania różnych technik, co jest wielką trudnością badań serologicznych, w których identyfikację różnych antygenów przeprowadza się w różnych warunkach za pomocą różnych testów. Badania serologiczne wymagają bardzo dużego doświadczenia. Opracowuje się automatyczne systemy kompleksowego fenotypowania najbardziej istotnych klinicznie antygenów erytrocytów.

Klasyczne metody oparte na reakcji PCR poddawane są także w miarę możności automatyzacji poprzez zastosowanie stacji pipetujących i programów komputerowych do ich obsługi. Automatyzacji podlegają etapy izolacji DNA i przygotowywania mieszanin reakcyjnych, a wyniki analizy moga być elektronicznie transferowane do baz danych. Dzięki tym modyfikacjom są tworzone systemy lub platformy badań o średniej przepustowości, pozwa- 
Tabela 1. Wyniki badań autorów porównujące techniki serologiczne i molekularne analizy grup krwi

Table 1. Results of blood group analysis with serological and molecular techniques; comparison

Watkins i wsp. [9]: 20266 próbek DNA przebadano równolegle metodami: BloodChip, HEA BeadChip, ID Core, fenotypowania. Wykryto:

-8 różnic między platformami genetycznymi;

- 44 różnice z serotypowaniem; u 18 możliwe ponowne fenotypowanie wykazało błędne wpisy wyników w systemie komputerowym PULSE

Haer-Wigman i wsp. [10]: 213 próbek DNA przebadano równolegle metodami: MLPA, fenotypowania. Wykryto:

- 17 błędów serologii;

- 3 błędy genotypowania: allele Kell null

Altayar i wsp. [11]: przebadano techniką NSG (Ion Torrent):

- FY (20 DNA); JK (32); ABO (12); RHD (6)

Keller i wsp. [12]: 70000 dawców przebadano równolegle metodami: HEA BeadChip; fenotypowanie. Wykryto:

-7 rozbieżności w oznaczeniu antygenów $\mathrm{Jk}^{\mathrm{a}} \mathrm{i} \mathrm{Jk}^{\mathrm{b}}$

Wagner i wsp. [13]: u 69947 dawców przebadano 7 polimorfizmów pojedynczego nukleotydu metodą spulowanej elektroforezy kapilarnej (PCE, pooled capilary elektroforesis)

Rieneck i wsp. [14]: u 20142 dawców przebadano 4 polimorfizmy pojedynczego nukleotydu metodą LGC Genomics KASPassay

lające na określenie kilku do kilkunastu antygenów u kilkudziesięciu osób dziennie.

Badania molekularne antygenów komórek krwi w coraz większym zakresie są wykonywane za pomocą testów komercyjnie dostępnych, produkowanych przez różnych producentów. Wybór testu zależy od zakresu i celów badań, a także od dostępności aparatury, często ściśle zależnej od producenta testu, oraz warunków lokalowych. Dotychczas w większości krajów badania molekularne są wykonywane w ośrodkach referencyjnych.

Zdaniem wielu ekspertów należy się jednak liczyć $z$ tym, że w nieodległej przyszłości rozszerzy się w znacznym stopniu typowanie antygenów komórek krwi u krwiodawców, a badania oparte na metodach analizy DNA nie tylko uzupełnią, ale zastąpią badania serologiczne dla oznaczania antygenów. Trzeba przy tym podkreślić, że wszyscy eksperci są zgodni, że badania molekularne nie zastąpią badań serologicznych w zakresie antygenów układu $\mathrm{ABO} z$ powodu zbyt skomplikowanego podłoża zmienności genu $A B O$. Za to badania obecności oraz swoistości przeciwciał są i pozostaną niezbędną częścią procesu doboru krwi do przetoczenia [16, 17].

Generalnie rozszerzanie zakresu typowania antygenów komórek krwi ma prowadzić do podwyższania bezpieczeństwa przetoczeń poprzez ograniczenie powikłań poprzetoczeniowych wynikających $z$ alloimmunizacji, a także zwiększenia dostępności dawców dla chorych $z$ przeciwciałami, tak by krew do przetoczenia była osiagalna dla wszystkich chorych w momencie, gdy są wskazania do dokonania przetoczenia, zgodnie $z$ zasadą: „właściwa krew, we właściwym czasie”. Perspektywy wprowadzenia masowych badań molekularnych u dawców i biorców krwi omówiono w wielu publikacjach [2, 18-19] i przedstawiono w tabeli 2.

Według opinii ekspertów pion krwiodawstwa powinien dążyć do wdrożenia masowych badań molekularnych w celu identyfikacji dawców antygenowo ujemnych pod względem klinicznie istotnych antygenów, szczególnie bez tzw. antygenów powszechnie występujących, czyli dawców rzadkich grup. W Polsce obowiązuje lista rzadkich grup zamieszczona w Załączniku 1 Rozporządzenia MZ z 09.02.2017 r.; Dz.U.2017.028.0000235. Krew zidentyfikowanych dawców rzadkich grup powinna być w miarę możliwości stale dostępna na wezwanie, a pobrane od nich koncentraty krwinek czerwonych $(\mathrm{KKCz})$ powinny być mrożone. Dane o takich dawcach i stanach zasobów mrożonych $\mathrm{KKC} z$ powinny być włączane do krajowego i międzynarodowego rejestru dawców rzadkich grup [20-23].

Perspektywa doboru krwi do przetoczenia na podstawie zgodności rozszerzonego fenotypu, obejmującego najbardziej immunogenne antygeny, wydaje się dość odległa, lecz też jest rozważana wobec postępu w badaniach genetycznych i bioinformatycznych [24].

Jak dotąd nie ma jednoznacznej opinii, która z nowych technologii badań antygenów komórek krwi będzie optymalna do masowych badań u krwiodawców. Badania nad ich zastosowaniem i optymalizacją trwają w wielu ośrodków, co omówiono w dalszej części artykułu.

W tabeli 3 wymieniono technologie i aparaturę, która jest obecnie dostępna do badań na dużą skalę. 
Tabela 2. Przyszłe zastosowanie masowych badań molekularnych dawców i biorców krwi

Table 2. Large-scale application of molecular screening of blood donors and recipients in the future

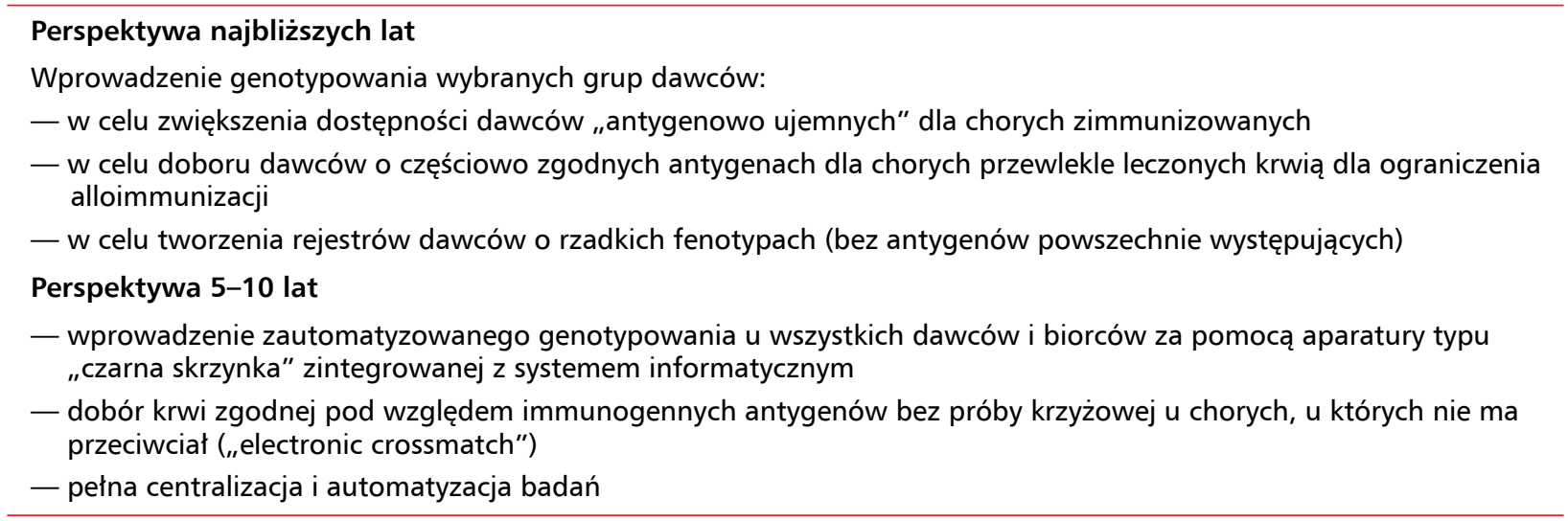

Tabela 3. Technologie i zestawy diagnostyczne umożliwiające masowe badania antygenów komórek krwi (w nawiasach podano nazwy producentów)

Table 3. Technologies and diagnostic kits for large-scale screening of blood antigens (manufacturers in brackets)

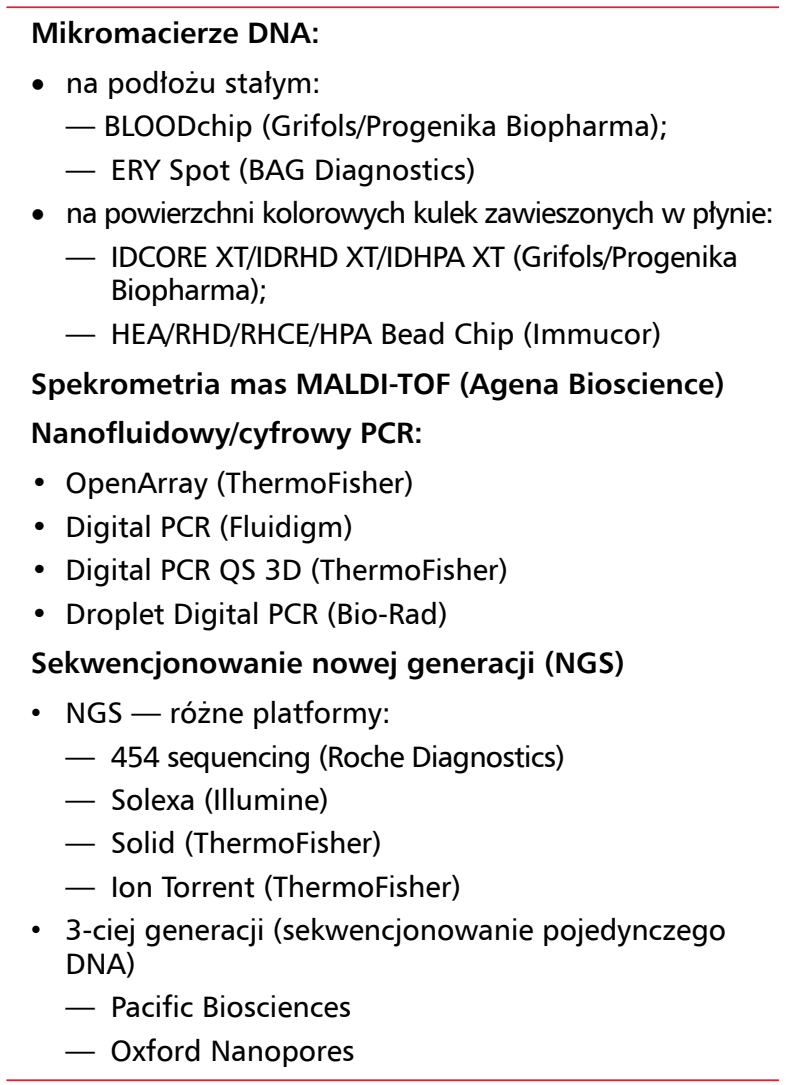

\section{Mikromacierze}

Technika mikromacierzy wykorzystuje zjawisko hybrydyzacji DNA do specyficznych sond związanych $\mathrm{z}$ podłożem stałym lub z mikrokulkami krzemionkowymi lub magnetycznymi.

Metoda detekcji produktów PCR przez hybrydyzację $z$ sondami swoistymi dla alleli jest $z$ nana i stosowana od wielu lat. Była to jedna $z$ pierwszych technik do genotypowania antygenów HLA [25]. Metodę tę opisywano pod nazwą PCR-SSO (PCR, sequence specific oligonucleotide), a podłożem, na które wiązano sondy, była bibuła, natomiast formą wywołania - barwna reakcja enzymatyczna. Wraz $z$ rozwojem nanotechnologii zminimalizowano materiały, na które nanoszono sondy, osiaggając przy szklanych mikropłytkach efektywność nadruku rzędu $1 \mathrm{mln}$ sond na $1 \mathrm{~cm}^{2}$ i wizualizując wyniki hybrydyzacji dzięki zastosowaniu fluorescencyjnie znakowanych barwników. Poszukiwano także sposobów, aby wytworzyć testy wykorzystujące klasyczne mikropłytki reakcyjne (96 lub 384-dołkowe), nanosząc sondy na dno studzienek, by tam zachodziły kolejne procesy płukania możliwe do obsługi pipetą wielokanałową albo pipetorem. Najmłodszą odmianą technologii mikromacierzy są metody bazujące na kolorowych mikrokulkach (silikonowych), do których wiąże się specyficzne sondy (jedna sonda - jeden kolor), a których analiza wykorzystuje zasady detekcji stosowane w cytometrii przepływowej. W systemach tych rozpoznawany jest kolor kulek, który ściśle definiuje rodzaj sondy, która została do niego przypisana.

Do identyfikacji poszczególnych alleli stosuje się sondy molekularne komplementarne do miejsc polimorficznych poszczególnych genów. Sekwencja i długość poszczególnych sond są tak dobrane, aby specyficznie wiązały się one do komplementarnych sekwencji w badanym DNA, kodujących poszczególne cechy i by tylko DNA związane $z$ sondą nie 
zostało odpłukane w następnym etapie badania. Dobór długości sond i ustalenie warunków inkubacji dla zajścia swoistego związania sond i warunków odpłukania niezwiązanego DNA jest najtrudniejszym wyzwaniem dla zespołów opracowujących i produkujących takie testy. Badane DNA poddaje się procesowi namnożenia fragmentów genów kodujących antygeny, a następnie poddaje hybrydyzacji z zestawem swoistych sond [26].

Historia konstruowania mikromacierzy do oznaczania antygenów erytrocytów zaczęła się ponad 10 lat temu. W latach 2003-2009 w ramach projektu finansowanego $z$ funduszy europejskich opracowano zestawy do oznaczeń antygenów krwinek czerwonych i płytek krwi, które wprowadzono na rynek przez firmę Progenika/Grifols (BLOODchip) $[27,28]$. Sondy naniesione są tutaj na szklaną płytkę. W ostatniej wersji testu - BLOODchip (Progenika/Grifols) - badanych było 10 układów grup krwi RBC (w nawiasach liczba badanych alleli): ABO (68); Rh: RHD+ (72); RHD- (23) RHD Del (10); RHD częściowe (47); RHD słabe (21); RhCE (25): C, c, Cw, Cx, E, e, Vs, Kell (18); Kidd (12); Duffy (13), MNS (21); Diego (3); Dombrock (3); Colton (3); Lutheran (3) i 12 układów HPA (1-11 i -15). Konstrukcja testów i aparatury do detekcji pozwalała na wykonanie badań około 24 próbek DNA w ciągu 10 godzin. Obecnie ten test nie jest już produkowany.

Analogiczne rozwiązanie było zastosowane w odczynnikach GenomeLab (Beckman Coulter); sondy nanoszono tu na dna studzienek płytki 384-dołkowej. Zestaw umożliwiał analizę 22 antygenów z 10 układów (MNS, RHD, RHCE, KEL, FY, JK, DI, HPA-1, 2, 5) [29]. Także naukowcy francuscy skonstruowali dla własnego pionu krwiodawstwa podobne testy oparte na płytkach 96-dołkowych, gdzie są nadrukowane sondy dla identyfikacji 24 alleli grup krwi (KEL1/2, KEL3/4; JK1/2; FY1/2; MNS1/2, $\mathrm{MNS} 3 / 4, \mathrm{FY}^{*}$ null; $\mathrm{FY} * \mathrm{X} ; \mathrm{YT} 1 / 2 ; \mathrm{CO} 1 / 2 ; \mathrm{DO} 1 / 2$, $\mathrm{HY}+$, Jo(a+); LU1/2; DI1/2). Proces badania 96 próbek krwi na 24 cechy zajmuje 4,5 godziny i został tak opracowany, że nie wymaga izolacji DNA, a materiałem do badań jest pełna krew pobrana na EDTA [30].

Na zbliżonej zasadzie oparte są testy do oznaczania antygenów krwinek czerwonych i HLA firmy BAG Diagnostics. Test ERY SPOT Common umożliwia oznaczenie antygenów $z$ układu Kell, Kidd, Duffy, MNS, test ERY SPOT weak-D type - identyfikację wariantu antygenu $\mathrm{RhD}$, natomiast ERY SPOT Rare - oznaczenie 14 antygenów rzadkich (Co, Di, Do, Lu, Vel, Kp, Js). Sondy naniesione są na dno studzienek w paskach po 8 sztuk, każdą studzienkę można wyłamać i dowolnie zestawiać typy testów, łącząc różne badania w ramach jednej procedury detekcji w skali 1-96 badań równocześnie. Proces trwa 2 godziny. Metoda ta jest skrzyżowaniem technologii mikromacierzy $z$ jej oprogramowaniem detekcyjnym opartym na pomiarze wyniku reakcji enzymatycznej $z$ zastosowaniem enzymu streptawidyny. Testy te mają znak CE i IVD [31].

W nowszej modyfikacji techniki mikromacierzy sondy są umieszczane na barwnych kulkach krzemowych. Technologia xMAP Luminex łączy ze sobą elementy cytometru przepływowego (optyka, lasery jako źródło światła, odczyt podczas przepływu przez kanał detekcyjny) z cyfrowym przetwarzaniem sygnału świadczącego o hybrydyzacji DNA do sond na mikrokulkach o 100 odcieniach koloru pomarańczowego, co daje elastyczność multipleksowania testów. Czas badania za pomocą takich zestawów jest krótszy - 96 próbek DNA bada się w ciągu 5 godzin. Tego rodzaju podejście zastosowano $\mathrm{w}$ innych zestawach testów firmy Grifols - BLOODchip ID $\mathrm{CORE}^{\mathrm{XT}}$, który pozwala zbadać status w zakresie 37 antygenów erytrocytów (49 alleli): RhCE, Kell, Kidd, Duffy, MNS, Di, Do, Co, YT, Lu, natomiast test BLOODchip ID HPA ${ }^{\mathrm{XT}}$ umożliwia wykrycie 32 genotypów w zakresie antygenów HPA (HPA1-11 i 15) płytek krwi. W opublikowanych międzynarodowych badaniach oceniono w warunkach rutynowego laboratorium immunohematologicznego funkcjonowanie obydwu testów [32-34]. Ustalono, że przy użyciu tej technologii można wykonać badania 87 próbek dziennie, czyli osiąga się przepustowość ponad 20000 badań rocznie. Po badaniach około 200 próbek każdym $z$ testów wykazano, że zgodność wyników testów $z$ wynikami testów dotychczas stosowanych wynosi $99,4 \%$ dla ID CORE ${ }^{\mathrm{XT}}$ względem testów serologicznych i $100 \%$ dla ID HPA ${ }^{\mathrm{XT}} \mathrm{w}$ porównaniu $z$ testami molekularnymi. Podobne wyniki zestawów BLOODchip ID COREXT uzyskali badacze japońscy [33]. Najnowszym testem firmy jest zestaw ID RHDXT, dedykowany do wykrywania najistotniejszych alleli null genu RHD (RHD*01N.01, *03N.01, *08N.01 (psi)) oraz alleli warunkujących antygen D słabe typ 1, 2, 3 (RHD*01W.1, *01W.2, *01W.3).

Nieznacznie inne rozwiązanie jest stosowane w testach opracowanych przez firmę BioArray Solutions, obecnie dystrybuowane przez firmę Immucor [35]. Tutaj zastosowano mikrokulki o wielu odcieniach, będących kombinacją fluorochromu 
fioletowego, niebieskiego i zielonego, a każda taka kulka ma pojemność związania ponad $1 \mathrm{mln}$ kopii jednorodnej sondy. Proces hybrydyzacji DNA namnożonego w multipleksowym PCR do różnych rodzajów zaprojektowanych kulek zachodzi w studzienkach płytki 96-dołkowej lub na szklanym slajdzie na 8 badań. Po zajściu hybrydyzacji następuje wydłużenie sondy $z$ użyciem znakowanych fluorescencyjnie terminujących nukleotydów. Jeśli dochodzi do specyficznej terminacji zdefiniowanym dla polimorfizmu nukleotydem, to możliwy jest odczyt fluorescencji przez system optyczny, działający na zasadzie mikroskopu. W ,polu widzenia” systemu optycznego znajduje się ponad 4000 kulek, po 50-60 w każdym kolorze, czyli specyficznych dla szukanych alleli. Oprogramowanie komputerowe dokonuje analizy koloru kulki $\mathrm{z}$ sygnalizowanych kolorem detekcji procesu mini-sekwencjonowania. Firma Immucor oferuje następujące zestawy do badań antygenów komórek krwi: 1) Immucor PreciseType ${ }^{\mathrm{TM}} \mathrm{HEA}$ ze znakiem CE IVD dla analizy 35 antygenów erytrocytów z 11 układów antygenowych $(\mathrm{C} / \mathrm{c}$, E/e, VS, V; K/k, Js ${ }^{\mathrm{a}} / \mathrm{Js}^{\mathrm{b}}, \mathrm{Kp}^{\mathrm{a}} / \mathrm{Kp}^{\mathrm{b}} ; \mathrm{Fy}^{\mathrm{a}} / \mathrm{Fy}^{\mathrm{b}}, \mathrm{Fy}^{\mathrm{x}}$, Fy*GATA; Jk ${ }^{\mathrm{a}} / \mathrm{Jk}^{\mathrm{b}} ; \mathrm{M} / \mathrm{N} ; \mathrm{S} / \mathrm{s}, \mathrm{U}-, \mathrm{Uv}^{\mathrm{ar}} ; \mathrm{Lu}^{\mathrm{a}} / \mathrm{Lu}^{\mathrm{b}}$; $\mathrm{Do}^{\mathrm{a}} / \mathrm{Do}^{\mathrm{b}}, \mathrm{Hy}+/ \mathrm{Hy}-, \mathrm{Jo}(\mathrm{a}+) / \mathrm{Jo}(\mathrm{a}-) ; \mathrm{Lw} ; \mathrm{Di}^{\mathrm{a}} / \mathrm{Di}^{\mathrm{b}}$; $\mathrm{Co}^{\mathrm{a}} / \mathrm{Co}^{\mathrm{b}}$; $\left.\mathrm{Sc} 1 / \mathrm{Sc} 2\right)$ oraz z dołączoną analizą mutacji warunkującej anemię sierpowatą (hemoglobina $\mathrm{S}$ ); 2) RHCE BeadChip (RUO, CE w EU) do oznaczania ponad 50 wariantów antygenów RHCE; 3) RHD BeadChip (RUO, CE w EU) do oznaczania 20 typów wariantów antygenu $\mathrm{D}$ słabe, 44 typów wariantów $\mathrm{D}$ częściowe, 3 typów antygenu DEL i 9 genotypów warunkujących fenotyp RhD ujemny; 4) HPA BeadChip (RUO, CE w EU) do oznaczania 11 układów antygenów HPA płytek krwi [36, 37].

Mimo wielu korzyści, jakie wiążą się z używaniem zwalidowanych testów komercyjnych, istotną ich wadą jest wysoka cena badania, szczególnie kompleksowych testów. Badania ograniczone są do wybranych, najbardziej użytecznych antygenów, więc wymagają uzupełniania o inne zestawy testów.

\section{Spektromeria mas MALDI-TOF}

Podstawą spektrometrii mas (mass spectrometry) jest pomiar stosunku masy do ladunku danego jonu podczas wędrówki w próżni. Można tą techniką analizować masę cząsteczek kwasów nukleinowych, m.in. zamplifikowanych fragmentów DNA, zawierających sekwencje różniące się pojedynczym nukleotydem, ponieważ w zależności od składu nukleotydów mają one różną masę (masa:
$\mathrm{dAMP}=313.2 \mathrm{Da}, \mathrm{dCMP}=289.2 \mathrm{Da}, \mathrm{dGMP}$ $=329.2 \mathrm{Da}$, dTMP = 304.2 Da). Do badań DNA stosuje się technikę MALDI-TOF, w której za pomocą jonizatora MALDI (Matrix Assisted Laser Desorption Ionization) doprowadza się do jonizacji cząsteczek DNA, a następnie w urządzeniu TOF (Time of Flight Analyzer), prowadzi w próżni rozdział cząsteczek na podstawie stosunku ich masy do ładunku. Całość procesu znajduje się pod nadzorem stosownego oprogramowania, które pozwala na analizę wyników. Cząsteczki DNA o różnych sekwencjach układają się w charakterystyczny wzór widma - lżejsze cząsteczki wędrują szybciej, cięższe wolniej, w zależności od algorytmu projektowanej długości poszczególnych amplikonów i różnic nukleotydów.

Metoda charakteryzuje się wysoką czułością i wysoką przepustowością; wykonanie oznaczeń jest możliwe w krótkim czasie. Badania konstruuje się na zasadzie PCR typu multiplex, gdzie w jednej reakcji powiela się do 40 loci, a jednoczesna analiza zależy od zastosowanego formatu płytki do PCR (24-, 96- lub 384-dołkowa).

Badania nad zastosowaniem technologii MALDI-TOF prowadzono $\mathrm{w}$ ramach wielkiego niemiecko-szwajcarskiego projektu w kooperacji $z$ firmą Sequenom, a obecnie Agena Bioscience Inc. (San Diego, CA) [38]. Pierwsze publikowane dane obejmowały analizę 13 polimorfizmów definiujących istotne klinicznie antygeny erytrocytów: $\mathrm{K} / \mathrm{k}, \mathrm{Jk}^{\mathrm{a} / \mathrm{b}} ; \mathrm{Fy}^{\mathrm{a} / \mathrm{b}}, \mathrm{x} / \mathrm{GATA}, \mathrm{M} / \mathrm{N}, \mathrm{S} / \mathrm{s}, \mathrm{Kp}^{\mathrm{a} / \mathrm{b}}, \mathrm{Lu}^{\mathrm{a}} / \mathrm{b}$, LU14/18, Yt ${ }^{\mathrm{a} / \mathrm{b}}, \mathrm{Co}^{\mathrm{a} / \mathrm{b}} ; \mathrm{HPA}-1 \mathrm{a} / \mathrm{b}$ [39]. Obecnie powstało kilka wariantów testów: 1) test przesiewowy dla dawców Hemo ID ${ }^{\mathrm{TM}}$ Donor Quick Screen DQS Module (analiza najistotniejszych 47 alleli z 12 układów grup krwi); 2) kompleksowy zestaw testów Hemo ID Blood Group Genotyping Panel dla analizy 101 antygenów erytrocytów z 16 układów grup krwi i 23 antygenów HPA/HNA oraz 6 zestawów testów przeznaczonych do analizy wybranych układów antygenowych dla celowanych amplikacji: Hemo ID KKD Module (antygeny Kell, Kidd, Duffy), Hemo ID MNS; Hemo ID Rare, Hemo ID RHD-RHCE, Hemo ID Variant RHD oraz Hemo ID HPA/HNA.

Badania przeprowadzone przez szwajcarski Czerwony Krzyż w Zurychu potwierdzają wysoką wydajność oraz wysoki poziom dokładności genotypowania tą techniką, $z$ wykorzystaniem testu Hemo ID Blood Group Genotyping Panel [40]. Autorzy wskazują jednak na ograniczenia tej metody - bardzo wysokie początkowe koszty oprzyrządowania oraz wysoką liczbę niezautomatyzowanych etapów badania, co wiąże się z obsłu- 
gą przez wyspecjalizowany personel i utrudnia masowe zastosowanie. Tym niemniej metoda MALDI-TOF została wprowadzona do użycia m.in. w laboratoriach niemieckich — w skali 380 próbek na dzień (Hemo ID ${ }^{\mathrm{TM}}$ Donor Quick Screen DQS Module).

\section{Nanofluidowy/cyfrowy PCR (digital PCR)}

Nanofluidowy PCR jest modernizacją techniki reakcji PCR $z$ pomiarem $\mathrm{w}$ czasie rzeczywistym polegającą na miniaturyzacji reakcji PCR. Osiągnięto to poprzez skonstruowanie płytek $z$ nano-studzienkami, w których reakcje PCR zachodzą $\mathrm{w}$ nano-objętościach. Taka strategia pozwala jednoczasowo przeprowadzić tysiące reakcji PCR na jednej płytce, w ilości odczynników używanych rutynowo do 96 badań na płytkach 96-dołkowych. W metodzie tej cząsteczki analizowanego DNA zostają rozprowadzone przez sieć mikrokanalików do odpowiednich mikrostudzienek, które znajdują się w konstrukcji kapilarnej płytki. Średnica tych kapilar pozwala na zdeponowanie pojedynczych cząsteczek DNA zawieszonych w buforze do PCR lub emulsji do emulgacyjnego PCR. Takie „naczynia”, z zawartymi w nich pojedynczymi cząsteczkami analizowanego DNA i składnikami mieszaniny koniecznymi do zajścia reakcji PCR, zostają poddane fluorescencyjnej amplifikacji. Gdy w mikroceli znajduje się cząsteczka DNA o analizowanej sekwencji, to reakcja zajdzie i zostanie ono namnożone, co da sygnał fluorescencji. Jeśli starter lub sonda nie odnajdzie w danej „mikroceli” komplementarnego DNA, reakcja PCR nie zajdzie. W podejściu ilościowym można zliczyć liczbę „mikrocel” $z$ dodatnimi i ujemnymi wynikami amplifikacji. Wynik ten nie jest zależny od liczby cykli reakcji PCR, ale odpowiada ściśle liczbie cząsteczek zawierających analizowaną sekwencję. Można téz przeprowadzać analizę w punkcie końcowym PCR m.in. $z$ zastosowaniem sond odmiennie znakowanych dla dyskryminacji alleli.

Testy oparte na tej zasadzie zostały opracowane przez firmę ThermoFisher (Open Array, QS 3D Digital PCR), Fluidigm (digital PCR), Bio-Rad (kropelkowy cyfrowy PCR - droplet digital PCR). Termocykler do płytek Open Array posiada blok na 4 nanopłytki z 3072 nanostudzienkami każda, co pozwala przeprowadzić w ciągu 4,5 godziny aż 12288 reakcji PCR. Nanopłytki Fluidigm $96 \times 96$ umożliwiają przeprowadzenie jednoczasowo 9216 reakcji PCR [41, 42]. System ddPCR Bio-Radu pozwala analizować w 96-dołkowej płytce do 20 000 kropelek, w których mogła zajść reakcja PCR.
Ilościowe badania techniką nanofluidowego PCR są użyteczne szczególnie dla nieinwazyjnych badań antygenów erytrocytów i płytek płodu w konfliktach serologicznych [43]. Znajdują też zastosowanie w badaniach klinicznie istotnych antygenów u dawców i biorców krwi. W pracy Hopp i wsp. analizowano użyteczność platformy OpenArray do oznaczeń antygenów krwinki czerwonej - antygenów E/e, Fy $/ \mathrm{Fy}^{\mathrm{b}}, \mathrm{Fy}^{\mathrm{x}} / \mathrm{Fy}{ }^{\mathrm{GATA}}, \mathrm{Jk}^{\mathrm{a}} / \mathrm{Jk}^{\mathrm{b}}, \mathrm{Lu}^{\mathrm{a}} / \mathrm{Lu}^{\mathrm{b}}$, $\mathrm{K} / \mathrm{k}, \mathrm{Js}^{\mathrm{a}} / \mathrm{Js}^{\mathrm{b}}, \mathrm{Do}^{\mathrm{a}} / \mathrm{Do}^{\mathrm{b}}$, Jo ${ }^{\mathrm{a}}$ i Hy [44]. Zbadanie DNA od 427 osób wykazało, że wśród ogólnej liczby 2037 oznaczeń, dla których były dostępne wyniki genotypowania i fenotypowania, w 5 przypadkach wyniki metod były rozbieżne. Zgodność uzyskano więc dla 99\% oznaczeń. Tę strategię badań wykorzystało duńskie krwiodawstwo, przeprowadzając analizę genotypu w 4 polimorfizmach antygenowych erytrocytów u 20142 w 2 miesiące [14].

\section{Sekwencjonowanie nowej generacji (Next Generation Sequencing)}

Rozwój technologii sekwencjonowania rozpoczął się od wielkiego wyzwania, jakim był projekt uzyskania pełnej sekwencji genomu ludzkiego (Human Genome Project) [45]. Jego efektem byl znaczący rozwój technologii sekwencjonowania, opracowanie oprzyrządowania do odczytywania sekwencji DNA, a także do gromadzenia i analizowania uzyskanych danych. Dostępne obecnie technologie pozwalają na dokonywanie sekwencjonowania o różnym zakresie. Jest możliwe sekwencjonowanie całego genomu, sekwencjonowanie eksonów (czyli DNA kodującego) lub sekwencjonowanie panelu wybranych fragmentów genów. Wraz z upowszechnieniem zastosowań dostępnych technologii NGS w diagnostyce medycznej koszt badań znacząco maleje.

Każda $z$ trzech wymienionych wyżej zasad badania ma różną użyteczność. W badaniach dotyczących polimorfizmów determinujących antygeny komórek krwi znajdują zastosowania przede wszystkim dwa podejścia - sekwencjonowanie eksonów oraz sekwencjonowanie wybranych fragmentów genów. Sekwencjonowanie eksonów $z$ założenia jest przydatne w sytuacjach, gdy celem badań jest ustalenie nieznanego podłoża swoistości antygenowej, która została zidentyfikowana w badaniach serologicznych. Przy użyciu technologii sekwencjonowania eksonów Cvejic i wsp. ustalili podłoże genetyczne antygenu Vel, który jest klinicznie istotnym antygenem o wysokiej częstości występowania [46]. Podobne badania pozwoliły na ustalenie podłoża antygenu o niskiej częstości 
występowania SARAH (SARA), wykrytego w australijskiej rodzinie [47, 48].

Najszersze zastosowanie praktyczne będzie $z$ pewnością miała trzecia $z$ wymienionych strategii, tzn. sekwencjonowanie NSG wybranych genów, kodujących grupy krwi i inne antygeny komórek krwi [49-52]. Technologia NGS ma znaczącą przewagę nad omówionymi w tej pracy wcześniej technologiami, które charakteryzują się, co prawda, wysoką lub średnią przepustowością i pozwalają na przebadanie szerokiego wachlarza genotypów antygenów istotnych klinicznie lub antygenów rzadkich, lecz ich znaczącym ograniczeniem jest fakt, że wprowadzane do użycia przez producentów platformy są zaprojektowane na wykrywanie zdefiniowanych wcześniej różnic jednonukleotydowych i ograniczone do wykrycia polimorficznego nukleotydu. Warianty spowodowane zmianą nukleotydu obok tego miejsca, a powodujące brak komplementarności starterów lub sond, mogą dawać wynik fałszywie ujemny oznaczenia istotnego klinicznie antygenu. Przewagą technologii NGS jest wgląd $\mathrm{w}$ rzeczywistą sekwencję badanego regionu kodującego grupy krwi i wykrycie ewentualnych wariantów w jej obrębie, przy czym ta technologia jest obecnie w fazie badań naukowych [53-54]. Techniki NGS w oznaczaniu grup krwi zostały szczegółowo omówione przez autorów niniejszego artykułu w osobnej publikacji, która niedawno się ukazała [55].

\section{Piśmiennictwo}

1. Denomme GA, Johnson ST, Pietz BC. Mass-scale red cell genotyping of blood donors. Transfus Apher Sci. 2011; 44: 93-99.

2. Flegel WA, Gottschall JL, Denomme GA. Integration of red cell genotyping into the blood supply chain: a population-based study. The Lancet Haematology. 2015; 2: e282-e288.

3. Wagner FF. Molecular testing in transfusion medicine. Expert Opin Med Diagn. 2010; 4(5): 411-428, doi: 10.1517/17530059.2010.506509, indexed in Pubmed: 23496198.

4. Veldhuisen B, van der Schoot CE, de Haas M. Multiplex ligation-dependent probe amplification (MLPA) assay for blood group genotyping, copy number quantification, and analysis of RH variants. Immunohematology. 2015; 31(2): 58-61, indexed in Pubmed: 26495890.

5. Latini FR, Gazito D, Arnoni CP, et al. A new strategy to identify rare blood donors: single polymerase chain reaction multiplex SNaPshot reaction for detection of 16 blood group alleles. Blood Transfus. 2014; 12 Suppl 1: s256-s263, doi: 10.2450/2013.024212, indexed in Pubmed: 23736910.

6. Hopp K, Weber K, Bellissimo D, et al. High-throughput red blood cell antigen genotyping using a nanofluidic real-time polymerase chain reaction platform. Transfusion. 2010; 50: 40-46.

7. Brouard D, Ratelle O, Perreault J, et al. PCR-free blood group genotyping using a nanobiosensor. Vox Sang. 2015; 108(2): 197-204, doi: 10.1111/vox.12207, indexed in Pubmed: 25469570.
8. Avent ND, Madgett TE, Halawani AJ, et al. Next-generation sequencing: academic overkill or high-resolution routine blood group genotyping? ISBT Science Series. 2015; 10(S1): 250-256, doi: $10.1111 /$ voxs.12148.

9. Watkins N. Blood group genotyping -SNPs to sequencing. Vox Sang 2013; 105 (4A-S34-01; 59(Suppl.1).

10. Haer-Wigman L, Ji Y, Lodén M, et al. Comprehensive genotyping for 18 blood group systems using a multiplex ligation-dependent probe amplification assay shows a high degree of accuracy. Transfusion. 2013; 53(11 Suppl 2): 2899-2909, doi: 10.1111/trf.12410, indexed in Pubmed: 23992446.

11. Altayar MA, Halawani AJ, Kiernan M, et al. Extensive genotyping of blood groups Duffy Kidd and ABO by next generation sequencing. Vox Sang. 2014; 107(supl. 1): 187.

12. Keller MA, Crowley JA, Horn T, et al. Kidd antigen discrepancies: genotype-predicted phenotype vs serologic phenotype. Vox Sang. 2014; 107(supl. 1): 37.

13. Wagner FF, Bittner R, Herrmann O, et al. Estimation of minor blood group antigen frequencies in high geographical resolution . Vox Sang.; 2014(Suppl 1): 195.

14. Rieneck K, Clausen FB, Erikstrup C, et al. Large scale genetic screening of donors in the Danish blood donor study (DBDS) for rare blood groups. Vox Sang.; 2014(Suppl 1): 191.

15. Peyrard T. Use of genomics for decision-making in transfusion medicine: laboratory practice. ISBT Science Series. 2013; 8(1): 11-15, doi: 10.1111/voxs.12002.

16. Westhoff CM. Molecular DNA-based testing for blood group antigens: recipient-donor focus. ISBT Science Series. 2013; 8(1): 1-5, doi: 10.1111/voxs.12049.

17. Svensson A, Delaney M. Considerations of red blood cell molecular testing in transfusion medicine. Expert Rev Mol Diagn. 2015; 15(11): 1455-1464.

18. Veldhuisen B, van der Schoot CE, de Haas M. Blood group genotyping: from patient to high-throughput donor screening. Vox Sang. 2009; 97(3): 198-206, doi: 10.1111/j.1423-0410.2009.01209.x, indexed in Pubmed: 19548962.

19. Flegel WA, Gottschall JL, Denomme GA. Implementing mass-scale red cell genotyping at a blood center. Transfusion. 2015; 55: 2610-2615.

20. Portegys J, Rink G, Bloos P, et al. Towards a Regional Registry of Extended Typed Blood Donors: Molecular Typing for Blood Group, Platelet and Granulocyte Antigens. Transfus Med Hemother. 2018; 45(5): 331-340, doi: 10.1159/000493555, indexed in Pubmed: 30498411.

21. www.isbtweb.org/working-parties/rare-donors.

22. Hustinx H. DGTI Register of Rare Donors. Transfus Med Hemother. 2014; 41(5): 338-341, doi: 10.1159/000366106, indexed in Pubmed: 25538534.

23. http://www.iblutspende.ch/en/rare-donors.html.

24. Hendrickson JE, Tormey CA, Shaz BH. Red blood cell alloimmunization mitigation strategies. Transfus Med Rev. 2014; 28(3): 137144, doi: 10.1016/j.tmrv.2014.04.008, indexed in Pubmed: 24928468.

25. Martinelli G, Buzzi M, Farabegoli P, et al. New strategies for selection of unrelated bone marrow donors. Bone Marrow Transplant. 1993; 11 Suppl 1: 31-32, indexed in Pubmed: 8448542.

26. Boccoz SA, Le Goff G, Blum LJ, et al. Microarrays in blood group genotyping. Methods Mol Biol. 2015; 1310: 105-113, doi: 10.1007/978-1-4939-2690-9_9, indexed in Pubmed: 26024629.

27. Avent ND, Martinez A, Flegel WA, et al. The Bloodgen Project of the European Union, 2003-2009. Transfus Med Hemother. 2009; 36(3): 162-167, doi: 10.1159/000218192, indexed in Pubmed: 21113258. 
28. Avent ND, Martinez A, Flegel WA, et al. The BloodGen project: toward mass-scale comprehensive genotyping of blood donors in the European Union and beyond. Transfusion. 2007; 47(1 Suppl): 40S-46S, doi: 10.1111/j.1537-2995.2007.01309.x, indexed in Pubmed: 17593285.

29. https://www.beckmancoulter.com.

30. Paris S, Rigal D, Barlet V, et al. Flexible automated platform for blood group genotyping on DNA microarrays. J Mol Diagn. 2014; 16(3): 335-342, doi: 10.1016/j.jmoldx.2014.02.001, indexed in Pubmed: 24726279.

31. https://www.bag-healthcare.com/en/diagnostics/transfusion-diagnostics/ery-spotr-sso/ery-spotr-products/.

32. Finning K, Bhandari R, Sellers F, et al. Evaluation of red blood cell and platelet antigen genotyping platforms (ID CORE XT/ ID HPA XT) in routine clinical practice. Blood Transfus. 2016; 14: $160-167$.

33. Tanaka M, Kamada I, Takahashi J, et al. Evaluation of a blood group genotyping platform (BLOODchip(®) Reference) in Japanese samples. Transfus Med. 2014; 24(1): 39-44, doi: 10.1111/ tme.12085, indexed in Pubmed: 24152224.

34. Goldman M, Núria N, Castilho LM. An overview of the Progenika ID CORE XT: an automated genotyping platform based on a fluidic microarray system. Immunohematology. 2015; 31(2): 62-68, indexed in Pubmed: 26495891.

35. Hashmi G, Shariff T, Seul M, et al. A flexible array format for large-scale, rapid blood group DNA typing. Transfusion. 2005; 45(5): 680-688, doi: 10.1111/j.1537-2995.2005.04362.x, indexed in Pubmed: 15847654.

36. Hashmi G, Shariff T, Zhang Y, et al. Determination of 24 minor red blood cell antigens for more than 2000 blood donors by high-throughput DNA analysis. Transfusion. 2007; 47: 736-747.

37. McBean RS, Hyland CA, Flower RL. Blood group genotyping: the power and limitations of the Hemo ID Panel and MassARRAY platform. Immunohematology. 2015; 31(2): 75-80, indexed in Pubmed: 26495893.

38. Gassner C, Meyer S, Frey BM, et al. Matrix-assisted laser desorption/ionisation, time-of-flight mass spectrometry-based blood group genotyping-the alternative approach. Transfus Med Rev. 2013; 27: 2-9.

39. Meyer S, Vollmert C, Trost N, et al. Validation of KEL (Kell) SLC14A1 (Kidd) and DARC (Duffy) MALDI-TOF MS high throughput blond group genotyping using $>3.100$ serologically pre-typed donor samples. Vox Snag. 2013; 105(suppl.1): 60.

40. Meyer S, Trost N, Frey BM, et al. Parallel donor genotyping for 46 selected blood group and 4 human platelet antigens using high-throughput MALDI-TOF mass spectrometry. Methods Mol Biol. 2015; 1310: 51-70, doi: 10.1007/978-1-4939-2690-9_5, indexed in Pubmed: 26024625.

41. http://www.thermofisher.com.
42. https://www.fluidigm.com.

43. Svobodová I, Pazourková E, Hořínek $\mathrm{A}$, et al. Performance of Droplet Digital PCR in Non-Invasive Fetal RHD Genotyping - Comparison with a Routine Real-Time PCR Based Approach. PLoS One. 2015; 10(11): e0142572, doi: 10.1371/journal. pone.0142572, indexed in Pubmed: 26562517.

44. Hopp K, Weber K, Bellissimo D. High-throughput red blood cell antigen genotyping using a nanofluidic real-time polymerase chain reaction platform. Transfusion. 2010; 50: 40-46.

45. Venter J, Adams M, Myers E, et al. The sequence of the human genome. Science. 2001; 291: 1304-1351.

46. Cvejic A, Haer-Wigman L, Stephens JC, et al. SMIM1 underlies the Vel blood group and influences red blood cell traits. Nat Genet. 2013; 45: 542-545.

47. Towns D, Hannon J, Hendry J, et al. Hemolytic disease of the fetus and newborn caused by an antibody to a low-prevalence antigen, anti-SARA. Transfusion. 2011; 51(9): 1977-1979, doi: 10.1111/j.1537-2995.2011.03107.x, indexed in Pubmed: 21414007.

48. McBean R, Hyland C, Roscioli T, et al. The low frequency SARAH blood group antigen: evidence for a new MNS antigen. Vox Sang. 2014; 107(Suppl 1): 17.

49. Erlich H. HLA DNA typing: past, present, and future. Tissue Antigens. 2012; 80(1): 1-11, doi: 10.1111/j.1399-0039.2012.01881.x, indexed in Pubmed: 22651253.

50. Quail MA, Smith M, Coupland P, et al. A tale of three next generation sequencing platforms: comparison of Ion Torrent, Pacific Biosciences and Illumina MiSeq sequencers. BMC Genomics. 2012; 13: 341, doi: 10.1186/1471-2164-13-341, indexed in Pubmed: 22827831.

51. Szymańska S, Studzińska S, Pareek C, et al. Techniki sekwencjonowania jako nowej generacji analityka w omice. Analityka. 2012; 3: 27-36.

52. Fichou Y, Audrézet MP, Guéguen P, et al. Next-generation sequencing is a credible strategy for blood group genotyping. $\mathrm{Br}$ J Haematol. 2014; 167(4): 554-562, doi: 10.1111/bjh.13084, indexed in Pubmed: 25135605.

53. Lane W, Westhoff $\mathrm{C}$, Uy J, et al. Comprehensive red blood cell and platelet antigen prediction from whole genome sequencing: proof of principle. Transfusion. 2016; 56(3): 743-54.

54. Montemayor-Garcia C, Westhoff CM. The „next generation” reference laboratory? Transfusion. 2018; 58(2): 277-279, doi: 10.1111/trf.14483, indexed in Pubmed: 29411394.

55. Orzińska A, Guz K, Brojer E. Potential of next-generation sequencing to match blood group antigens for transfusion. Int J Clin Transfusion Med 2019;7: 11-22. doi: 10.2147/IJCTM. S175142. 